\title{
STUDY THE OVERVIEW OF RECENT MANAGEMENT OPTIONS FOR POLYCYSTIC OVARIAN DISEASE
}

Kavita Chandnani, Kunda Jawalkar

1. Associate Professor,Department of Obstetrics \& Gynecology, SBKSMIRC and Dhiraj General hospital.

2. Assistant Professor, Department of Obstetrics \& Gynecology, SBKSMIRC and Dhiraj General hospital.

\section{CORRESPONDING AUTHOR:}

Dr. Kavita Chandnani,

A-20, Sunderam Park Society,

B/H Bright School, VIP Road,

Karelibaug, Vadodara - 390018, Gujarat, India.

E-mail: kavyawch@rediffmail.com

ABSTRACT: Infertility, though not a physically debilitating disease, severely affects the couples' psychological, harmony, sexual life and social functions. With all the modern needs of contraception rising on one side, infertility is still a major challenge to the gynecology practitioners on the other hand.

Male \& Female contribute to the fertility of a couple and factors affecting any of reproductive organs can alter the fertile potential. Of all the factors contributing to female infertility due to ovarian disturbances, Polycystic Ovarian disease is the leading one.

PCOS is the commonest endocrine disease in women of reproductive age. It affects 5-10 $\%$ of women of reproductive age. 1 It is associated with increased androgen secretion, hirsutism , menstrual irregularities and infertility. It has impact not only on physical but also on mental health of women. PCOS now proves to be a significant factor in female infertility with prevalence of 0.6 to $3.4 \%$ in infertile couples. It is noted in $30-50 \%$ of women with RPL (recurrent pregnancy loss).2 With improving laboratory facilities, sonography and with routine laparoscopic evaluation of infertility. PCOD has shown a remarkable increase of incidence in recent years.

The aims of this study are 1 . To know the patho-physiology of PCOS \& its clinical correlation 2. To evaluate investigations 3 . To compare recent modality of management options $\&$ their outcome.

KEY WORDS: PCOS-INFERTILITY-MENSTRUAL IRREGULARITY

INTRODUCTION: Polycystic Ovarian disease was described as early as $19^{\text {th }}$ century. In1935 Stein \& Leventhal described syndrome of amenorrhea associated with polycystic ovaries 3.

PCOS is the commonest endocrine disease in women of reproductive age. It affects 5-10 $\%$ of women of reproductive age. PCOS now proves to be a significant factor in female infertility. As women with PCOS are at increased risk of diabetes, hypertension, cardiovascular disease, hyperestrogen related cancers; it requires thorough evaluation \& treatment. With growing experience since the beginning of $21^{\text {th }}$ century various modalities with varying results have come into existence for its management.

Weight loss and dietary changes appears to affect all parameters of hormonal fluctuation. For menstrual irregularities, O.C.Pills is excellent choice of drug. Cyclic Progestin may be alternative. Antiandrogens are effective for excess hair growth. To trigger ovulation, Medical management with ovulation inducing drugs like Clomiphene Citrate is the first choice of 
treatment for anovulation. Metformin most widely used insulin sensitizer for ovulation induction in patients with insulin resistance. Surgical Management with reduction of androgen production improves ovarian response to gonadotropins.

\section{AIMS AND OBJECTIVES}

1) To study pathophysiology of PCOS \& its clinical correlation.

2) To evaluate different investigations for PCOS.

3) To establish different diagnostic criteria.

4) To compare recent modality of management options \& their outcome

5) Long term follow up reduce consequence

\section{Diagnostic Criteria for PCOS}

Major:

1) Chronic Anovulation

2) Hyperandrogenemia

3) Clinical Signs of Hyperandrogenism

Minor:

4) Elevated LH: FSH ratio

5) Insulin Resistance

6) Perimenarchal onset of Hirsuitism \& Obesity

7) Intermittent anovulation associated with hyperandrogenemia

\section{INVESTIGATIONS:}

Ultrasonography: on TVS

- Thickness of tunica albuginea

- Hyperthecosis

- Multiple subcapsular cysts of 5-8 mm diameter

- Increased volume of ovary L X W X T X 0.523

On basis of USG, two type of PCO pattern have been identified ${ }^{19}$ :

1) Peripheral cystic pattern

Small cysts are located in the subcapsular region and arranged in a "NECKLACE" or "STRIN OF PEARL" pattern.

2) General cystic pattern

Small cysts of variable size occupy both subscapular region and stromal part of ovary Increased endometrial thickness due to unopposed estrogen stimulation in PCOS patients.

\section{Color Doppler \& 3D Scan in PCO:} Laboratory Investigation for Hormonal Evaluation:

1) Gonadotropins: S. LH, S. FSH level should be done on day 2 of cycle.

2) Androgens: S. Testosterone: Increased S. DHEA \& Androstenedione: Increased SHBG; Decreased

3) Estrogens:

Total E2: Normal

Free / Unbound E2: Elevated due to decreased SHBG Serum estrone E1 ; Increased

4) Prolactin: Increased 
5) Others:

S. TSH to rule out thyroid disorders.

Test for insulin resistance like $\mathrm{S}$. insulin, fasting glucose, and fasting glucose: INSULIN RATIO, 2 HR gtt ETC.

Laparoscopy: Diagnostic and therapeutic purpose.

TREATMENT

1) Treatment of Menstrual Irregularities: O.C. Pills are drug of choice and combination of ethinyl estradiol and Metformin.

2) Treatment of Obesity: Weight reduction

3) Treatment of Hirsutism: Hormonal Therapy: OC Pills, Medroxy Progesterone, GnRH analogues, Glucocorticoids Antiandrogens: Spironolactones, Cyproterone Acetate, Flutamide Enzyme Inhibitors: Ketoconazole ,Finasteride Mechanical Method: Depilatory creams, Electrolysis, Laser hair removal, Waxing, Shaving, Bleaching etc.

4) Treatment of Infertility: Ovulation Induction can be achieved medically or surgically.

Clomiphene citrate: first line of drug is a weak synthetic estrogen but it mimics the action of an estrogen antagonist when used for ovulation induction in case of PCOS, starring dose should be $50 \mathrm{mg} /$ day on day 2 to day 6 after onset of menses. Ovulation should be documented using TVS. Inj. HCG 10000 IU can be used for follicular rupture and followed by planned relations or IUI.

Results: Ovulation rate $-80-85 \%$

Pregnancy rate $-40-45 \%$

Side Effects: Nausea, Breast pain, Pelvic discomfort, vasomotor flushes, Multiple

Pregnancy.

Metformin: It is the most widely used insulin sensitizer for ovulation induction.

$500 \mathrm{mg}$ once a day breakfast $\mathrm{x} 4$ days

$500 \mathrm{mg}$ twice a day with breakfast \& dinner $\mathrm{x} 4$ days

$500 \mathrm{mg}$ with breakfast \& $1000 \mathrm{mg}$ twice a day. Thereafter up to $1000 \mathrm{mg}$ twice a day.

Result: Ovulation rate $70 \%$

Pregnancy rate $30 \%$

Gonadotropins: Various injectable preparations of HMG containing equal amount of FSH (75 IU) and LH (75IU) or highly purified FSH derived from recombinant DNA technology can be used. This treatment requires daily injection and close monitoring using TVS and S. estradiol.

Letrozole: It is aromatase inhibitors. Aromatase is an enzyme that converts androgen to estrogen.

\section{Surgical Management:}

Ovarian Wedge Resection

Laparoscopic Electrocauterisation of Ovarian Surface (LEOS)/ Laparoscopic Ovarian Drilling.

Treatment of Associated Factors:

Treatment of hypothyroidism

Treatment of oligospermia

Bromocriptine for hyperprolactinemia etc. 


\section{Materials and Methods}

Present study is based on 100 patients of proved polycystic ovarian syndrome with chief complaints of menstrual irregularity and infertility. Suspected cases of PCOD sent for USG and special investigations.

Polycystic Ovarian Syndrome was proved by

- Clinical Signs and symptoms

- TVS

- Laparoscopy

- Laboratory Investigations

Summary and Conclusion: 100 cases of proved PCOD patients are studied with chief complaints of infertility and menstrual irregularities.

Majority of patients belong to 20-30 years of age group. Mean age of patients is 25 years suggesting it to be the disease of younger patients. Majority of patients came with complaints of infertility, menstrual irregularity(41\%), Hirsutism (15\%), Obesity (20\%).

Ultrasonography (TVS) showed changes of PCOD in 82\% while in remaining cases the ovaries appeared normal suggesting that anatomical variation is not the pathophysiology mechanism behind the disease.

All patients in this study were treated with a view to achieve fertility.

a) Clomiphene Citrate: Ovulation rate $50 \%$ and conception rate $20 \%$

b) Metformin: Ovulation rate $70 \%$ and conception rate $23.3 \%$

c) Laparoscopic Ovarian Drilling: Ovulation rate $80 \%$ and conception rate $65 \%$.

CONCLUSION: Polycystic ovarian syndrome is common endocrinopathy seen in women of reproductive age. However, confusion still exists over precise etiology. Interestingly PCOS is associated with wide spectrum of diverse clinical features. Role of insulin resistance, hyperandrogenism and a genetic predisposition have enhanced our understanding of conception.

Advances in technology have improved our efforts towards an accurate diagnosis. Multiple beneficial therapeutic options are available \& have to be individualized in the management of PCOS patients. PCOS has significant long term metabolic impact on multiple organ systems and thus requires thorough evaluation to improve the quality of life of these.

\section{BIBLIOGRAPHY}

1. Asbjorn Aakavaag, Halvard Gjonnaess British Jrnl of Obst. 7 Gyn. Vol. 92, 1985.

2. Barbieri RL. Am Jrnl of Obst.Gyn. 2003.

3. Calvo RM et al; role of Follistatin gene in women with PCOS.

4. Clark AM, Thornley B., Tomlinson et al Hum. Repro. 1998, 13; 1502-1505.

5. Dewaart MJ et al infertility 1987: 10: 33-39.

6. Dickey et al, Hum Repro 1997.

7. Dunaif, A. 1997 Endo. Review 18; 774-800.

8. Farquhar, C., Vandeker ckhove, P., Arnot, M. \& lilford R. 2001.

9. Felemban A, Tan SL, Tulandi T., Fertil Steril 2000, 73; 266-269.

10. Fox er al, 1991, Robinson 1992.

11. Fox R., Aust NSJ Obst. Gynaecol 1999; 39; 63-68.

12. Franks Gharani N., Waterworth D et al Hum. Repro. 12, 1997: 2641-48. 
13. Franks, J., Adams, H. and Mason D.1995 clinical obstet Gynaecol 12: 603-633.

14. Glueck et al, J. Phillips, H. Cammeron, D. Sieve - smith L., Wang P. 2001-2002.

15. Glueck et all 2001 Coetzee \& Jackson 1984, 85 Heard et al 2002.

16. Greenblatte 7 Casper R American J Obst. \& Gyn. Vol. 92, 1985

17. Hisao Sumioki, Michio korenaga fertility \& Sterility Vol. 50 No.4 1988.

18. James F. Daniell, Wayne Miller Fertility \& Sterility Vol. 51 No. 21989.

19. Kolodziejezyk B et al Feril Steril 2000, 73 ; 1149-1154.

20. Mitwally MF, Casper RF, Fertil Steril 2001; 75: 305-309.

21. Naether OGJ et al Fertil Steril 1993; 60: 95-98.

22. Nestler J., Stovall D., Akhter S., Luorno M., \& Jakubowicz D 2002.

23. Nestler R., Powers, L., Matt, W., Steingold K., Plymate R., Rittjmaster S. 1991.

24. Nestler, J., Jakubowicz, J., Lurono, J., 2000 J Pediatr., Endocrinol. Metab.S: 1295-1298.

25. Neveu N, Granger L, St. Michel P lavoie Fertil Steril 2007, 87, 113-120.

26. Norman, J., Davies, J., and Moran J., 2002. J. Endocrinol Metab, 13: 251-257.

27. Rosenfied RL, Barnes, RB., Cara JF. \& luckey. A.W. Fertility \& Sterility 53, 1990, 7785- 91.

28. Rotterdam ESHRE/ ASRM PCOS consensus workshop revised 2003, Fertil Steril 2003, $81 ; 19-25$.

29. Seli, E. and Duleba J. 2002. Hum. Repro. 17, 2230-2236.

30. Speroff, L. Glass R \& Kase G. 1999 clinical Gyn, Endo. \& Infertility $6^{\text {th }}$ edition 487-521.

31. Stadtmauer LA, Toma K, Rient M \& Tablert M 2001 Fertil Steril 2001; 75, 505-509.

32. Stadtmauer, A.,laurel, C.,\& Sergio 2002 Hum. Repro, 17, 3016-3025.

33. Stein et al, Am Jrnl of Obst. Gynecol 1948.

34. Stein IF and Leventhal ML. 1935 American Jrnl of Obst. \& Gyn., 58, 181-191.

35. Yen et al, J of clin endocrine \& Metab 1970.

36. Yen, 1980; lobo et all 1981 Shoupe, kumar \& lobo 1983.

\section{OBSERVATION AND DISCUSSION}

Table: 1: Age Distribution of PCOD Cases:

\begin{tabular}{|c|c|c|}
\hline Age of Patients (Years) & Total no. of cases & Percentage \\
\hline Less than 20 & $\underline{06}$ & $6 \%$ \\
\hline Between 21-25 & 58 & $58 \%$ \\
\hline Between 26-30 & 34 & $34 \%$ \\
\hline More than 30 & 02 & $02 \%$ \\
\hline
\end{tabular}

Table: 2: Frequency of complaints:

\begin{tabular}{|l|c|c|}
\hline \multicolumn{1}{|c|}{ Chief complaints } & Total no. of cases & Percentage \\
\hline Infertility & 100 & $100 \%$ \\
\hline Menstrual Irregularities & 41 & $41 \%$ \\
\hline Hirsuitism & 15 & $15 \%$ \\
\hline Obesity & 20 & $20 \%$ \\
\hline
\end{tabular}

All patients studied basically came with complaints of infertility followed by menstrual irregularities.

Table: 3: Types of Infertility

\begin{tabular}{|c|c|c|}
\hline Type of infertility & Total no. of cases & Percentage \\
\hline Primary & 60 & $60 \%$ \\
\hline Secondary & 40 & $40 \%$ \\
\hline
\end{tabular}


Table: 4: Value of Luteinizing Hormone(LH)

\begin{tabular}{|c|c|c|}
\hline Luteinizing Hormone & Total no. cases & Percentage \\
\hline Elevated & 85 & $85 \%$ \\
\hline Normal & 15 & $15 \%$ \\
\hline
\end{tabular}

Normal LH Value in follicular phase 5-20 mlU/ML.

Table: 5: Follicular Stimulating Hormone (FSH)

\begin{tabular}{|c|c|c|}
\hline FSH & Total no. cases & Percentage \\
\hline Normal & 94 & $94 \%$ \\
\hline Below Normal & 06 & $06 \%$ \\
\hline
\end{tabular}

Normal FSH Value in follicular phase 4.5-20 mlU/ML.

Table: 6: LH: FSH Ratio:

\begin{tabular}{|c|c|c|}
\hline LH: FSH Ratio & Total no. of cases & Percentage \\
\hline $1-1.5$ & 12 & $12 \%$ \\
\hline $1.6-2$ & 32 & $32 \%$ \\
\hline$>2$ & 55 & $55 \%$ \\
\hline
\end{tabular}

Normal LH:FSH ratio is around 1 in early follicular phase.

Table: 7: Success Rates with Different Regimens:

\begin{tabular}{|l|c|c|c|c|}
\hline $\begin{array}{l}\text { Modality of } \\
\text { Treatment }\end{array}$ & $\begin{array}{c}\text { Total no. } \\
\text { cases }\end{array}$ & $\begin{array}{c}\text { Ovulatory } \\
\text { Rate }\end{array}$ & $\begin{array}{c}\text { Conception } \\
\text { Rate }\end{array}$ & $\begin{array}{c}\text { Abortion } \\
\text { Rate }\end{array}$ \\
\hline $\begin{array}{l}\text { Clomiphene } \\
\text { Citrate }\end{array}$ & 30 & $50 \%$ & $20 \%$ & $33.3 \%$ \\
\hline Metformin & 30 & $70 \%$ & $23.3 \%$ & $14 \%$ \\
\hline $\begin{array}{l}\text { Laparoscopic } \\
\text { Ovarian Drilling }\end{array}$ & 40 & $80 \%$ & $65 \%$ & $19.23 \%$ \\
\hline
\end{tabular}

Table: 8: Overall Results of Treatment:

\begin{tabular}{|c|c|c|c|c|c|}
\hline & $\begin{array}{c}\text { Treatment } \\
\text { Given }\end{array}$ & $\begin{array}{c}\text { Ovulatory } \\
\text { Rate }\end{array}$ & $\begin{array}{c}\text { Conception } \\
\text { Rate }\end{array}$ & $\begin{array}{c}\text { Live } \\
\text { birth }\end{array}$ & $\begin{array}{c}\text { Abortion } \\
\text { Rate }\end{array}$ \\
\hline $\begin{array}{c}\text { Total no. } \\
\text { cases }\end{array}$ & 100 & 68 & 39 & 31 & 8 \\
\hline Percentage & $100 \%$ & $68 \%$ & $39 \%$ & $79.49 \%$ & $20.51 \%$ \\
\hline
\end{tabular}




\section{PATHOPHYSIOLOGY OF PCOS}

Normal events in the ovary leading to ovulation:

A. Sufficient FSH stimulation for initial follicular recruitment and growth of dominant follicle.

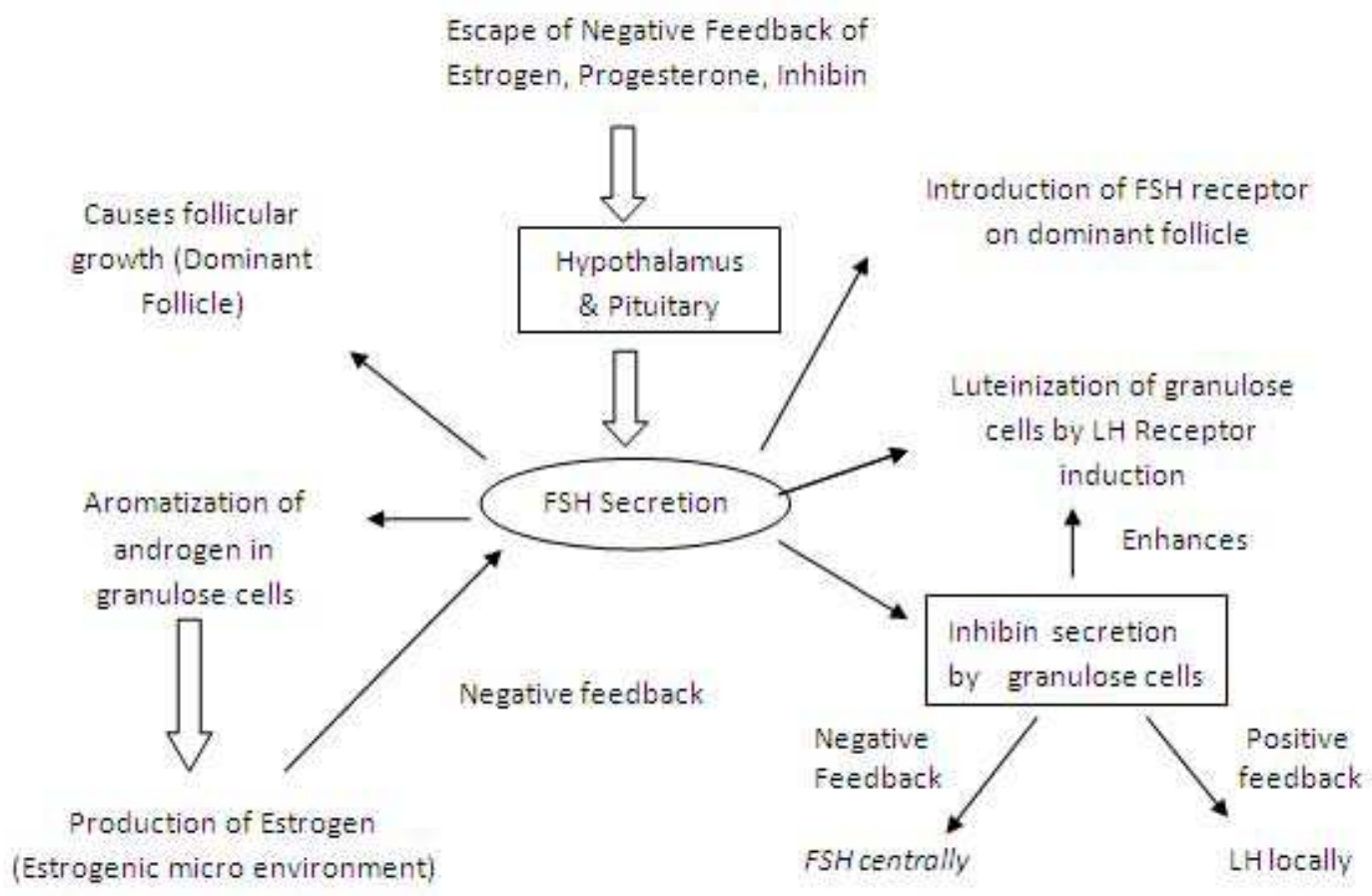

PCOS \& Obesity: 35-60 \%, usually android type. BMI > 27 KG/ SQ. M. ; Waist hip ratio $>0.85$ \& Waist $>100 \mathrm{~cm}$ usually associated with hyperinsulinemia.

Hyperandrogenism with chronic Anovulation: 50-60 \%

Hyperinsulinemia and PCOS Insulin Resistance,: Causes

- Peripheral Target tissue resistance

- Decreased Insulin Receptor Number

- Decreased Insulin Receptor Binding

- Post Receptor Failure most important

- Decreased Hepatic Clearance

- increased Pancreatic Sensitivity 


\section{ORIGINAL ARTICLE}

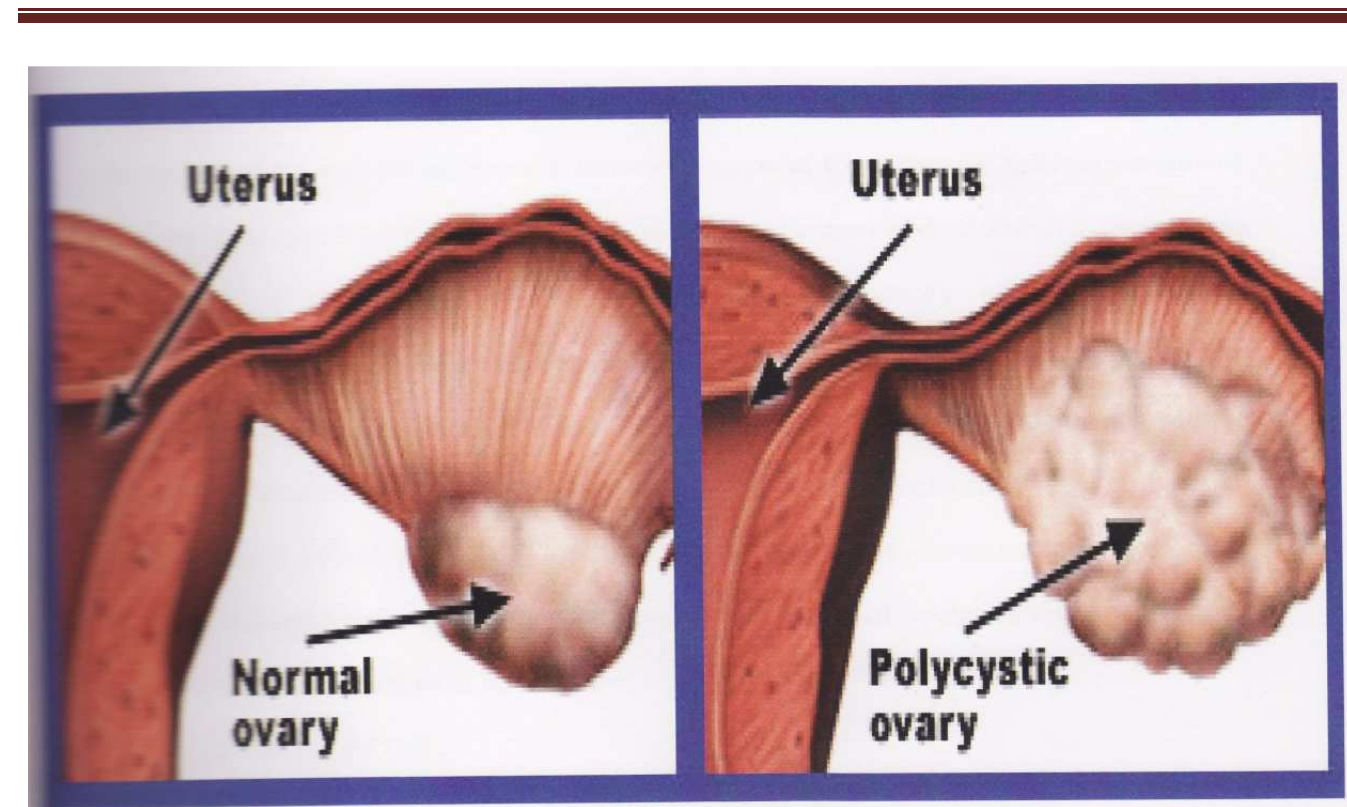

\section{PCOS AT GLANCE}

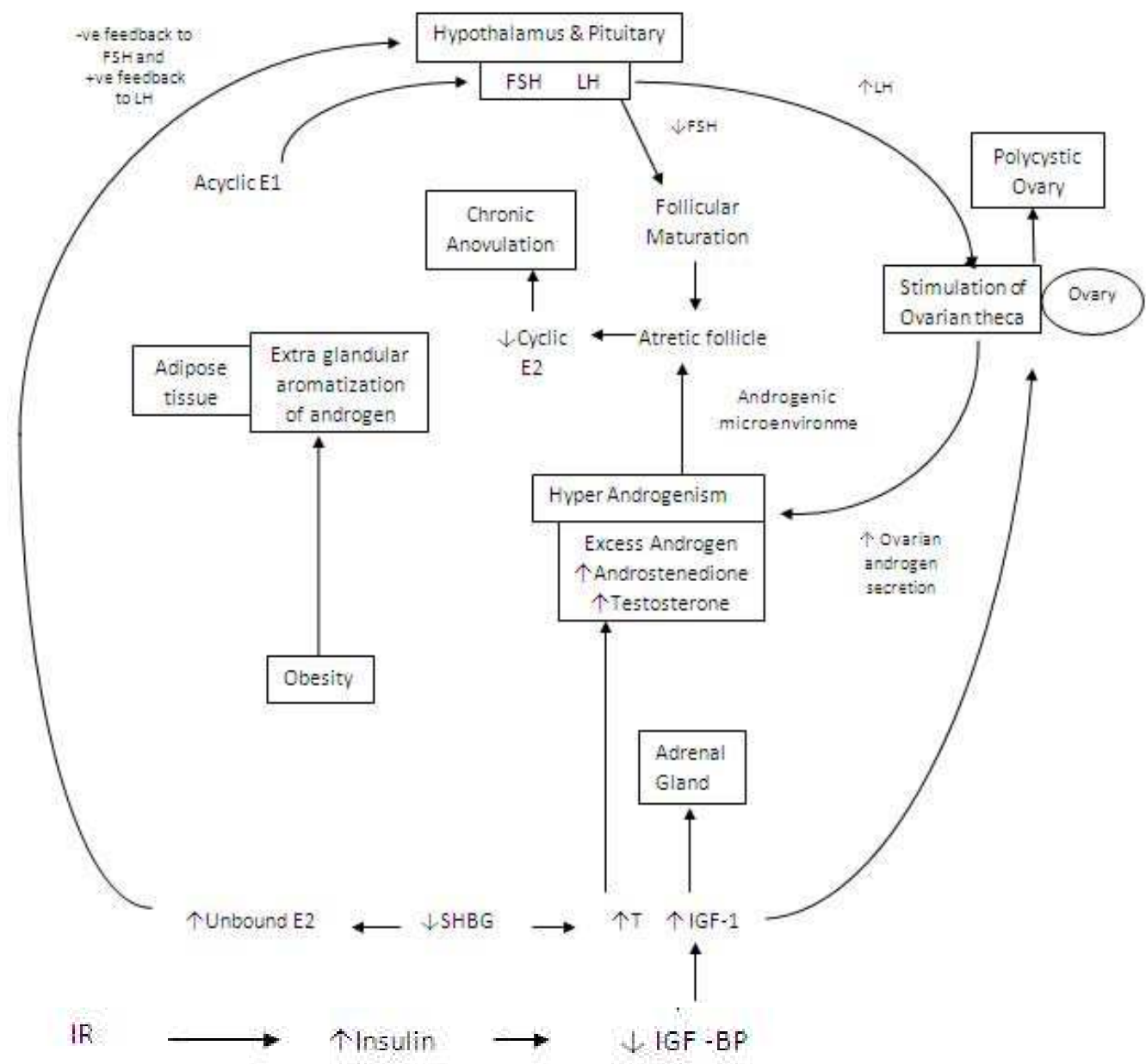




\section{Symptomatology and Clinical Features}

1. Infertility

2. Menstrual Irregularities

3. Hirsuitism

4. Obesity

5. Depression And Anxiety

Long Term Consequence of PCOS:

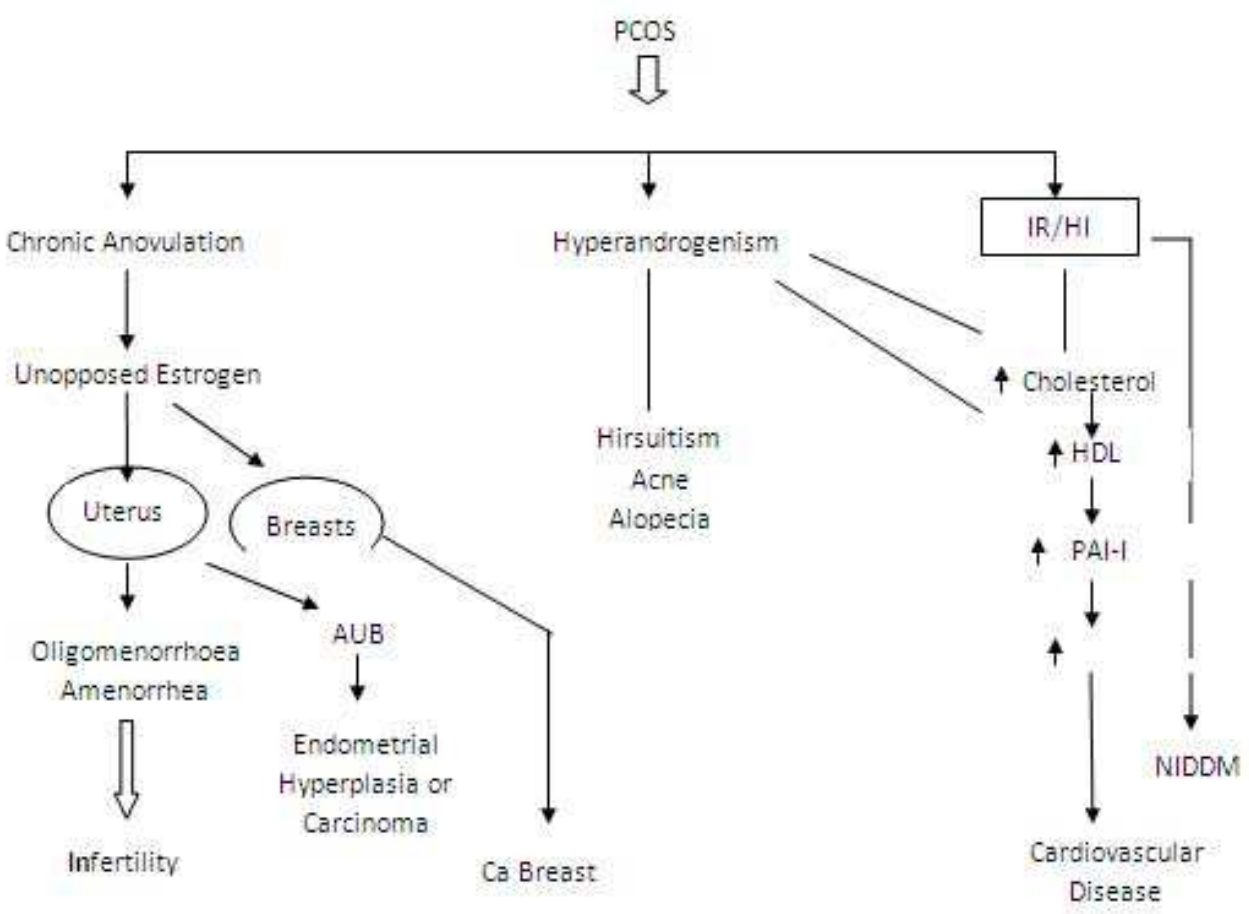

